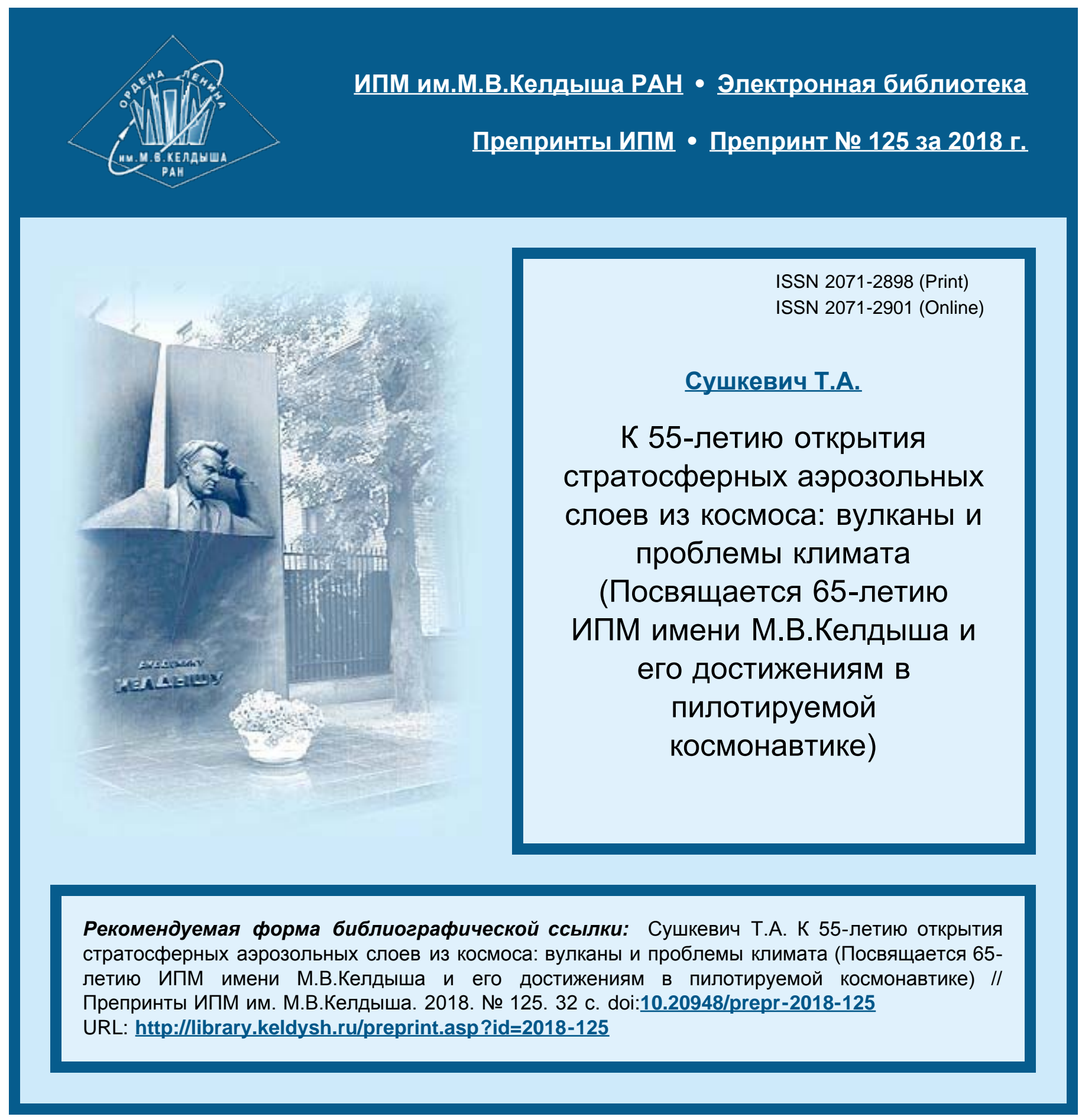




\author{
О рд е н а Л е н и н \\ ИНСТИТУТ ПРИКЛАДНОЙ МАТЕМАТИКИ \\ имени М.В.Келдыша \\ Российской академии наук
}

\title{
Т.А.Сушкевич
}

К 55-летию открытия стратосферных аэрозольных слоев из космоса: вулканы и проблемы климата

(Посвящается 65-летию ИПМ имени М.В.Келдыша и его достижениям в пилотируемой космонавтике) 


\section{Суикевич T.A.}

К 55-летию открытия стратосферных аэрозольных слоев из космоса: вулканы и проблемы климата (Посвящается 65-летию ИПМ имени М.В.Келдыша и его достижениям в пилотируемой космонавтике)

Цель настоящей публикации - обратить внимание на класс больших задач аэрокосмического дистанционного зондирования и глобального мониторинга климата Земли. В июне 2018 года отмечается 55-летие ПЕРВОГО в истории мировой науки научного эксперимента, осуществленного космонавтами на пилотируемых «кораблях-спутниках». Это был ПЕРВЫЙ научный эксперимент по дистанционному зондированию Земли из космоса. Обнаружили стратосферные аэрозольные слои, образованные вследствие мощных извержений вулкана Агунг на острове Бали в 1963 году. Извержения вулкана Агунг в 2017-2018 годах напомнили о пионерских достижениях советских космонавтов и ученых в освоении космического пространства. Руководил экспериментом Г.В.Розенберг. Публикация посвящена 65-летию Института прикладной математики имени М.В.Келдыша РАН, который 55 лет назад в июне 1963 года обеспечил баллистические расчеты космических кораблей «Восток-5» и «Восток-6» и успешный полет советских космонавтов В.Ф.Быковского и В.В.Николаевой-Терешковой - первой женщины-космонавта.

Ключевые слова: вулкан Агунг, стратосферные аэрозольные слои, дистанционное зондирование из космоса, пилотируемая космонавтикаТатаra Alexeevna Sushkevich

To the 55th anniversary of the discovery of stratospheric aerosol layers from space: volcanoes and climate problems (Dedicated to the 65th anniversary of the Keldysh Institute of Applied Mathematics and its achievements in manned cosmonautics)

The purpose of this paper is to draw attention to a class of large problems of aerospace remote sensing and global monitoring of the Earth's climate. In June 2018, the 55th anniversary of the FIRST scientific experiment in the history of world science, carried out by cosmonauts on manned «spacecraft- sputnik», is celebrated. It was the FIRST scientific experiment on remote sensing of the Earth from space. Stratospheric aerosol layers formed due to the powerful eruptions of Agung volcano in Bali in 1963 were discovered. The eruptions of Agung volcano in 2017-2018 reminded of the pioneering achievements of Soviet cosmonauts and scientists in the exploration of space. Guided by the experiment G.V.Rosenberg. This paper is devoted to the 65th anniversary of the Keldysh Institute of Applied Mathematics, which 55 years ago in June 1963 provided the ballistic calculations of spacecraft «Vostok-5» and «Vostok-6» and the successful flight of Soviet cosmonauts V.F.Bykovsky and V.V.Nikolaeva-Tereshkova - the first woman-cosmonaut.

Key words: Agung volcano, stratospheric aerosol layers, remote sensing from space, manned space exploration 


\section{1. Введение}

Настоящая работа посвящается

- 65-летию ПЕРВОГО в мировой науке и мировой практике Института прикладной математики имени М.В. Келдыша Академии наук («Институт Келдыша» основан в 1953 году) [1-2], который обеспечил баллистические расчеты для запусков и полетов ПЕРВЫХ искусственных спутников Земли (ИСЗ) и полетов ПЕРВЫХ пилотируемых космических кораблей (ПКК), которые первоначально называли «космические корабли-спутники»;

- достижениям пилотируемой космонавтики и памяти Главного Теоретика Космонавтики, Трижды Героя Социалистического Труда, академика Мстислава Всеволодовича Келдыша (10.02.1911, Рига, - 24.06.1978, Москва), со дня кончины которого 24 июня 2018 года исполняется 40 лет; в Институте Келдыша обеспечивались расчеты для полетов и стыковок в космосе пилотируемых космических кораблей, а затем и Долговременных орбитальных станций (ДОС) - ПЕРВАЯ орбитальная научная станция «Салют» была запущена в Советском Союзе 19 апреля 1971 года; ПЕРВАЯ стыковка в космосе ДОС и ПКК произошла 24 апреля 1971 года: ПЕРВЫЙ ПКК «Союз-10» пристыковался к ДОС «Салют»; 17 июля 1975 года в 19 часов 12 минут состоялась стыковка советского космического корабля «Союз-19» и американского «Аполлон» [3-4];

- 55-летию создания в 1963 году Института медико-биологических проблем Академии Наук по инициативе М.В.Келдыша, который был главным идеологом пилотируемой космонавтики в СССР и обеспечил приоритеты в пилотируемой космонавтике на многие десятилетия, которые никто не превзошел до настоящего времени; концепцию пилотируемой космонавтики поддерживали академики Гурий Иванович Марчук (08.06.1925-24.04.2013) и Кирилл Яковлевич Кондратьев (14.06.1920-01.05.2006); не случайно именно эти три научные школы - Московская, Ленинградская, Новосибирская - были ПИОНЕРАМИ в покорении космоса и становлении дистанционного зондирования Земли из космоса (ДЗ3) [5-16]; после неудачного полета орбитальной космической станции «Скайлэб» (SkyLab - небесная лаборатория) в США предпочитали автоматические аппараты: запуск «Скайлэба» состоялся 14 мая 1973 года, повышение солнечной активности в 1978-1979 годах «столкнуло» «Скайлэб» с орбиты (не было средств коррекции орбиты!), 11 июля 1979 года станция вошла в земную атмосферу и разрушилась [17];

- 100-летию со дня рождения академика Александра Михайловича Обухова (05.05.1918-03.12.1989) - ученика академика Андрея Николаевича Колмогорова, основателя и первого директора (1956-1989) Института физики атмосферы Академии наук [18-20], сотрудники которого [21-25] и ученики Евграфа Сергеевича Кузнецова [26] принимали активное участие в покорении космоса и открытии космической эры; 
- 55-летию ПЕРВОГО инструментального оптического исследования земной атмосферы из космоса с пилотируемого космического корабля - проект ИФА АН СССР и МИЭиА МАП с участием «Института Келдыша»;

- 55-летию ПЕРВОГО научного эксперимента по дистанционному зондированию атмосферы Земли из космоса (ДЗЗ) - проект ИФА АН СССР при участии «Института Келдыша»;

- 55-летию ПЕРВОГО в мировой практике научного эксперимента, проведенного человеком в космосе с борта пилотируемого космического корабля - проект ИФА АН СССР при участии «Института Келдыша»;

- 55-летию полета в космос ПЕРВЫХ «космических экспериментаторов»: летчика-космонавта № 5 Валерия Федоровича Быковского (14-19 июня 1963 г. на ПКК «Восток-5», приземлился 19.06.1963 в 11 часов 06 минут, затем ПКК «Союз-22», «Сою3-31»/«Союз-29») и летчика-космонавта № 6 Валентины Владимировны Николаевой-Терешковой (16-19 июня 1963 г. на ПКК «Восток6», приземлилась 19.06.1963 в 8 часов 20 минут) - ПЕРВОЙ женщиныкосмонавта; обучали космонавтов Анатолий Борисович Сандомирский (МИЭиА МАП) и Александр Константинович Городецкий (ИФА АН СССР);

- 55-летию обнаружения ВПЕРВЫЕ из космоса стратосферных аэрозольных слоев и обоснования их вулканического происхождения [27-31];

- 80-летию открытия ионосферы Земли (плазменной оболочки планеты) и 60-летию открытия радиационных поясов Земли [32-35];

- 55-летию научной деятельности в области космических исследований Тамары Алексеевны Сушкевич (автора публикации), начатой в «Институте Келдыша» АН СССР в 1963 году после окончания физического факультета Московского университета имени М.В.Ломоносова (специальность «теоретическая и математическая физика», кафедра «математики» А.Н.Тихонова, академика и в то время уже Героя Социалистического Труда за «водородную» бомбу - Указ Верховного Совета от 4 января 1954 года).

Первые работы Т.А.Сушкевич [36-38] были посвящены математическому моделированию на самой большой ЭВМ «Весна» [38] прохождения ракет и спутников через ионосферу и радиационные пояса Земли, которые были открыты в 1958-1959 гг.: «внутренние пояса» Ван Алленом с «Эксплорер-1» и «Эксплорер-2» и «внешние пояса» Сергеем Николаевичем Верновым (11.07.1910-26.09.1982), Александром Евгеньевичем Чудаковым (16.06.192125.01.2001), Александром Игнатьевичем Лебединским (07.01.1913-09.09.1967), Валерьяном Ивановичем Красовским (14.06.1907-04.12.1993) с советских космических станций «Луна-1» и «Луна-2» [33-35]. Эта тематика имеет отношение к космическому климату и заслуживает отдельной публикации, тем более что не исчезли угрозы ядерных взрывов в космосе и, как следствия, возникновения искусственных радиационных поясов и загрязнения атмосферы, что и произошло после Чернобыльской аварии в апреле 1986 года.

Настоящая публикация посвящена профессору Георгию Владимировичу Розенбергу (29.04.1914-09.12.1982) - одному из ПИОНЕРОВ покорения 
космического пространства и создания основ космических исследований, который стоял у истоков создания современной космической оптики для аэрокосмического ДЗ3. В условиях жесткого противостояния и жесточайшей конкуренции с США в 40-ые - 60-ые годы 20-го века стояла стратегическая задача обеспечения «ракетно-ядерного щита» для безопасности СССР и его союзников, в рамках которой необходимо было разработать не только средства доставки «изделия» в другое полушарие Земли, но и по гениальной инициативе Главного Теоретика Космонавтики М.В.Келдыша были начаты разработки по системам ПРО, «космической разведке» и космическим средствам обнаружения старта ракет для упреждения нанесения удара («УС-К»). Полеты космических аппаратов со спецаппаратурой над чужими территориями были запрещены и наблюдения могли проводиться только по наклонным трассам и в области горизонта Земли. В 1962 году была подготовлена первая «Программа атмосферно-оптических исследований из космоса», в рамках которой были запланированы научные эксперименты на пилотируемых и автоматических космических кораблях с целью изучения структуры и оптических свойств атмосферы и особенно её дневного и сумеречного горизонта.

Г.В.Розенберг теоретически обосновал ПЕРВЫЙ эксперимент для исследования земных сумерек из космоса [27-31] и обеспечил успешную обработку и объективный анализ космических данных [31, 39-42]. Прежде чем сообщить об открытии стратосферных аэрозольных слоев, проводились тщательные теоретико-расчетные исследования (при участии автора статьи), которые были продолжены в последующих космических экспериментах [4344]. В итоге в 1971 году была опубликована ПЕРВАЯ в мировой науке модель высотной стратификации атмосферного аэрозоля разного происхождения - это было ПЕРВОЕ открытие высотной оптической структуры земной атмосферы [42]. Исследования, продолженные по программе «Союз-Аполлон» [4, 45], подтвердили вулканическое происхождение аэрозольных слоев в верхней стратосфере.

\section{2. Как вулкан Агунг помог обнаружить стратосферные аэрозольные слои в 1963 году}

Начало работы автора по сопряженным задачам о природе аэрозольных загрязнений атмосферы (экологии) и их влиянии на динамику изменения климата совпало с началом 21 сентября 2017 года активности вулкана Агунг на острове Бали [46-48], который напомнил о пионерских работах 55-летней давности, связанных с этим же вулканом [31]. Известно, что в 1808 и 1821 годах вулкан генерировал незначительные извержения, а в 1843-м произвел мощный взрыв. Известно, что после последнего взрывного события Агунг заснул на 120 лет, а проснувшись в 1963 году, привел к величайшей катастрофе на острове Бали. Подробная хронология событий и рассказы очевидцев извержения вулкана Агунг отражены на сайте [49]. 
Вулкан Агунг пробудился 18 февраля 1963 года. Местные жители услышали грохот и заметили пепловую колонну, поднявшуюся над кратером. 24 февраля из вентиляционных отверстий вершины начали вырываться лавовые потоки, которые в течение последующих 20 дней протянулись на расстояние около 7 км. Время от времени гигант выбрасывал небольшие глыбы камней, фонтанировал лавой, которая разрушила горные тропы. Рост активности Агунга пришелся на середину марта. Вечером 16 марта участились выбросы пепла, а на следующий день масштабный взрыв полностью уничтожил всё живое в округе. Над кратером Агунга взметнулась гигантская пепловая колонна (по разным оценкам, высотой от 19 до 26 км). 16 мая, спустя почти месяц после первого извержения, на его вершине прогремел еще один взрыв, высота пеплового столба над Агунгом составила около 20 км. Зафиксированы похожие типы извержений: извержение, вспышка, лавовые потоки, эффузивные потоки горячих облаков, пепла, песка, пирокластические потоки (смесь горячего газа, пепла и камней). Умеренное извержение вулкана продолжалось до 27 января 1964 года, после чего он затих и сохранял спокойствие до 21 сентября 2017 года.

Новые признаки активности Агунг начал подавать в сентябре 2017 года; были зарегистрированы слабые сейсмические толчки и вибрация. К середине октября вулкан успокоился, но затем ожил снова; 21 ноября произошел фреатический (газовый) взрыв - магма вступила в контакт с холодной водой, и из кратера вылетели горячий газ, камни и лавовые бомбы. Облако дыма и пепла поднялось на 3,8 километра над уровнем моря (высота самого вулкана составляет 3142 метра). Фреатический взрыв перешел в фреамагматическую стадию, облако вулканических газов и пепла поднялось еще выше - на 1,5-4 километра над кратером. В ночь на 27 ноября началось новое извержение, отнесенное вулканологами к пелейскому типу. При пелейских извержениях образуются горячие тучи вулканических газов и пепла, а по склонам вулкана сползают лавины очень вязкой низкотемпературной лавы. Столб газов и пепла достиг высоты 9144 метров [46-48].

Последствия извержения вулкана Агунг в 2017 году ещё предстоит оценить. В настоящей публикации представлены результаты исследований последствий длительного извержения вулкана Агунг с 18 февраля 1963 года по 27 января 1964 года. Климатологи и метеорологи зафиксировали, что температура Земли в 1963 году снизилась на 0,4 градуса по Цельсию. И совсем случайно с таким природным явлением совпало проведение ПЕРВОГО научного эксперимента по исследованию оптической структуры земного горизонта, наблюдаемой из космоса, на советских пилотируемых «корабляхспутниках» «Восток-5» и «Восток-6» в интересах разработки систем упреждения стартов ракет из космоса для обеспечения «ракетно-ядерного щита» в СССР. Эксперимент позволил не только обнаружить стратосферные аэрозольные слои, но и объективно подтвердить и обосновать природу их 
происхождения, а также исследовать релаксацию аэрозольного загрязнения верхней стратосферы во времени в масштабах планеты.

Аэрозольные слои, образованные как последствия извержения вулкана Агунг, просуществовали около двух лет. Это было ОТКРЫТИЕ в мировой науке! Возможности существования и формирования стратосферных аэрозольных слоев предсказывались учеными [50-53]. Наиболее значимые результаты были получены Юнге, именем которого стратосферные слои названы «слои Юнге» [54-59]. Но из космоса инструментально ВПЕРВЫЕ «слои Юнге» были обнаружены «сумеречным методом» советскими учеными [30-31], которые к тому времени имели многолетний опыт успешных исследований атмосферы этим методом [27-29, 50-52]. Сумеречный метод в эти же годы активно использовали американские исследователи [60], которые подтвердили открытия советских ученых при наблюдениях последствий извержения вулкана Агунг в земных условиях [61-62].

\section{3. Сумеречный метод дистанционного зондирования атмосферы}

Пятая часть земной поверхности постоянно окутана сумерками (на заходе и восходе Солнца) [63]. На экваторе они длятся в общей сложности почти одну десятую часть года, а на полюсе (белые ночи) - около трети года. Не случайно большое место занимают земные и космические зори на восходах и заходах Солнца в поэтических описаниях природы. Но истинные причины столь обыденных и, пожалуй, самых красочных явлений природы найдены не так давно. Оказалось, что главную роль играет строение тех высоких слоев атмосферы, куда устремляются ныне ракеты и высотные самолеты. Это открыло возможность, находясь на земле и наблюдая течение сумерек, получать сведения о состоянии атмосферы на самых различных высотах. Что же такое сумерки и какие сведения можно получить с их помощью?

Веками воспевали поэты красоты древнегреческой богини зари, юной «розовоперстой» Эос, появляющейся всегда в новых праздничных одеждах, чтобы возвестить восход солнца. Но неведомым оставалось ее происхождение. В эпоху раннего средневековья в XI веке представление об атмосфере высказал арабский ученый и врач Ибн ал-Хасан, или, на латыни средневековья, Альгазен (965-1039). Это он первый понял, что существует свет - нечто материальное, исходящее от светящихся тел, свет, который, попав в наш глаз, создает у нас ощущение «светлоты».

По мнению большинства историков науки Альгазен является родоначальником научного метода. Выдающийся физик, математик, астроном, врач и философ-комментатор Аристотеля, Альгазен стал основоположником опытной науки, сочетая тщательные эксперименты со строгим математическим доказательством всех своих утверждений. Известнейший во всем мире его фундаментальный труд по оптике «Книга оптики» (в 7 книгах), который 
переведен на английский язык [64], а также «О свете светил», «О формах затмений» и т.д. Аль-Хайтам Аль-Хайтам Оптика / The optics of Ibn alHaytham (A.I.SABRA, 1989) состоит из семи книг:

1) О зрении и о глазе,

2) О распространении света,

3) Об ошибках зрения,

4) Об отражении от зеркальных поверхностей,

5) О воображении,

6) Об ошибках зрения при отражении от плоских, цилиндрических и конических зеркалах,

7) О преломлении света и об ошибках зрения при преломлении.

Тщательное исследование анатомии глаза и феноменов оптических иллюзий, привело Альгазена к собственной теории зрения: зрительный образ получается при помощи лучей, которые испускаются видимыми телами и попадают в глаз - для доказательства своих утверждений изобретается камераобскура, изучаются линзы, сферические зеркала, небесные явления - солнечный свет, радуга, сумерки, плотность воздуха, атмосферная рефракция.

Тщательно изучив зрение, Альгазен узнал, что мы видим не сами окружающие нас предметы, а их изображение на глазном дне, и что изображение это создают лучи Солнца, отразившиеся от поверхности предметов. Свет голубого неба - тоже свет Солнца, отраженный воздухом. Когда Солнце скрывается за горизонтом, небо меркнет, воздух становится невидимым и уже не заслоняет света звезд. Значит, лазурное дневное небо это не мистическое место для поселения богов, а наше, земное небо, светящееся одеяние самой Земли.

Интересна попытка Альгазена определить высоту атмосферы по величине сумерек. Солнце, опустившись под горизонт, ещё продолжает посылать рассеянные атмосферой лучи: этим обусловлены зори. Продолжительность сумерек даёт Альгазену возможность утверждать в соответствии с наблюдениями древних, что граница их соответствует углу опускания Солнца под горизонтом в $10^{\circ}$. Отсюда, считая атмосферу равномерно-плотной и имеющей границу, отражающую лучи, и наблюдая за продолжительностью сумерек, Альгазен оценивал высоту атмосферы в 52000 шагов (примерно 40 километров). Несмотря на неточность расчёта, указанную впоследствии Кеплером (предположение однородности атмосферы), следует признать метод Альгазена оригинальным и интересным.

Физика XVII века фактически состояла из двух разделов - механики и оптики, для которых общей областью применения была астрономия. Чтобы удовлетворить нужды астрономии, Иоганн Кеплер (1571-1630) в 1604 году написал фундаментальный труд по оптике «Ad Vitellionem paralipomena, quibus astronomiaepars optica traditur» («Паралипомены к Вителлию»), который он скромно рассматривал (это видно из самого названия) как простое дополнение к оптике Вителлия, т.е. к оптике Альгазена. В 1611 г. вышла книга Кеплера 
«Диоптрика». Именно с этих трудов начинается оптика как наука. В 1604 году Иоганн Кеплер уточнил расчеты Альгазена. Но сама идея расчета оставалась зыбкой: гениальной догадки в ней было больше, чем истинного знания. Надо было еще доказать, что воздух отражает свет, и узнать, как он его отражает и рассеивает. В своих работах Кеплер [65] подробно изложил геометрическую концепцию. Он описал преломление света, оптическое изображение, рефракцию, общую теорию о линзах и их системах.

12 апреля 1961 года человек впервые увидел свою планету извне и воскликнул: «Планета ГОЛУБАЯ!». Трудно даже вообразить обилие ощущений и впечатлений, выпавших на долю первого космонавта за его короткий полет. Но больше всего привлекли его внимание красота голубого ореола, окутывающего земной шар, и радужные переливы на границе дня и ночи. Уделив им значительную часть своего первого рассказа, Юрий Гагарин тут же прозаически добавил, что все выглядело так, как предвидели ученые.

Однако воздух никогда не бывает чистым. В нем всегда витают инородные частицы: пылинки, капельки воды, кристаллики льда, споры растений (эти взвеси объединяют под общим названием «аэрозоль»). Они тоже рассеивают свет, но иначе, чем молекулы, и окраска рассеянного света зависит от размеров и природы частиц. Заслуживают ли внимания эти ничтожные частички, случайно смешавшиеся с воздухом? Да, и даже самого пристального. Ведь сам воздух меняется очень мало и рассеивает свет всегда почти одинаково. Такое рассеяние воздуха называется молекулярным или релеевским. Но как сильно изменяется ото дня ко дню оптическое состояние атмосферы! То она очень прозрачна, и можно различать горы, отстоящие на сотни километров, то все окутывается густой непроглядной дымкой.

В этом виноваты исключительно частицы аэрозоля, очень изменчивые и почти неуловимые, - многие из них мы обнаруживаем только по помутнению воздуха. Именно густые облака пылинок придают желтовато-белесый цвет атмосфере Венеры. Следовательно, от присутствия аэрозоля, от размеров, концентрации и происхождения частиц зависят условия видимости и освещения и даже тепловой режим самой атмосферы, почвы и сельскохозяйственных культур. Напомним, что для защиты садов от мороза их окуривают дымом, то есть одевают в облако аэрозоля. Искусственные облака аэрозолей используются для маскировки. Поэтому очень важно узнать, как распределяется аэрозоль в воздушном океане, как он изменяется и переносится. Тогда откроются перед нами пути не только для прогноза влияния этого явления на нашу жизнь, но и для активного вмешательства в жизнь природы. Прямой путь к этому - изучение той световоздушной дымки, которая на Земле застилает отдаленные предметы днем, а на высоте становится видимой с Земли в сумеречные часы.

Атмосферная оптика, подобно астрономии, является одной из древнейших наук, она всегда занимала видное место в процессе познания окружающего мира. Происходящие в природе разнообразные атмосферно- 
оптические явления с давних пор привлекали внимание людей. Человек не только любовался красотой утренних и вечерних зорь, многоцветием радуг, удивлялся различного рода гало (в древних русских летописях они назывались галосами), загадочными венцами около Луны и Солнца, глориями, нимбами, миражами и т. д., но хотел проникнуть в тайны их возникновения, отгадать, понять наблюдаемые им явления [66-67].

Многие явления атмосферной оптики по народным приметам считались предвестниками погоды. Так, говорили, что чистый золотистый или бледно-розовый закат - к хорошей погоде, багрово-красные зори - к ненастью. Малое гало считалось предвестником дождливой погоды (чем сильнее гало - тем скорее будет дождь). В книге М.Миннарта «Свет и цвет в природе» [68] (которую Г.В.Розенберг назвал эпитафией чисто наблюдательному этапу атмосферной оптики) указывается, что дождь начинается в среднем через 36 часов после появления гало. Гало возникает благодаря преломлению света в кристалликах льда. Радиус малого гало составляет $22^{\circ}$, что соответствует углу наименьшего отклонения для правильной шестиугольной призмы. В отличие от радуги внутренний край гало красный, наружный - синий. Венцы представляют собой концентрические радужные кольца вокруг источников света и возникают вследствие дифракции на каплях воды, кристалликах льда и прочих неоднородностях среды. Их можно наблюдать в облаках вокруг Солнца и Луны, на оконных стёклах вокруг источников света, над чашкой чая и даже в собственном глазу!

В этой поэтической и познавательной книге Марсела Миннарта, известного голландского астронома бельгийского происхождения, увлекательно написано о больших и малых секретах природы, в которые может проникнуть внимательный наблюдатель, не имеющий каких-либо приборов и не обладающий специальными знаниями. Можно узнать и о тайнах миражей, и об иллюзиях при наблюдении НЛО, о нимбах на фотографиях, о том, какого цвета звезды, можно ли закат отличить от рассвета Солнца и о многих других загадках света. При необычном распределении плотности воздуха по высоте из-за значительного различия температур вблизи поверхности земли и на небольшой высоте горизонт может казаться ближе или дальше, чем обычно. Иногда земля кажется выпуклой, а горизонт - совсем близким. В других случаях поверхность земли может выглядеть как огромная вогнутая чаша, а горизонт - необычайно далёким, становятся видимыми далёкие объекты, которых обычно не видно. При данных явлениях изменяется видимая высота горизонта.

На первом этапе проблема использования сумеречных явлений для оптического зондирования атмосферы Земли впервые, после Альгазена (XI век) и Кеплера (1604), была выдвинута советским астрономом и основоположником астрофизики академиком Василием Григорьевичем Фесенковым (13.01.188912.03.1972) [50-51]. Первые построения теории яркости, поляризации и рефракции света в атмосфере Земли основаны на геометрической картине 
освещения планеты солнечными лучами в условиях наблюдения с земной поверхности дневного и сумеречного неба. По мнению Г.В.Розенберга, впервые такая задача была сформулирована схематически швейцарским физиком Paul Gruner (13.02.1869-1.12.1957) в 1919 году [69]. Приближения однократного рассеяния солнечного света в сферически симметричной земной атмосфере разрабатывались В.Г.Фесенковым в 1923 году [50], F.Link в 1933 году [70], Субраманьян Чандрасекаром (19.10.1910-21.08.1995) в 1934 году [71], ученицей В.Г.Фесенкова ученой и монахиней, астрофизиком и геофизиком, оптиком Ниной Михайловной Штауде (1888-16.06.1980) в монографии 1936 года [7276], учеником Сергея Ивановича Вавилова специалистом по исследованию верхних слоев атмосферы и серебристым облакам Иваном Андреевичем Хвостиковым (1906-07.08.1969) в 1936 году [77-79]. В 1940 году [79] И.А.Хвостиков впервые представил фундаментальный обзор теоретических и экспериментальных данных, в котором отражены особенности и молекулярного и аэрозольного рассеяния: Часть I. Молекулярное рассеяние света. Часть II. Рассеяние света крупными частицами.

Теория сумерек Н.М.Штауде имела большую практическую и военную, оборонную ценность, особенно учитывая, что в то время не было спутников и возможности непосредственного определения плотности и температуры воздуха на высотах порядка 80 км и выше. Г.В.Розенберг [27-29] приближенные сферические модели разрабатывал для применения фотометрических наблюдений сумерек как метода изучения стратосферы и верхней атмосферы. Сумеречные исследования могут быть распространены на значительно большие высоты и обеспечивают лучшее высотное разрешение, чем дневные.

Второй этап формирования сумеречного метода (с 1945 года) связан с выяснением роли вторично рассеянного света и началом ракетных исследований верхней атмосферы [66-67].

Эпохальным оказался третий этап - этап становления и совершенствования сумеречных исследований планетных атмосфер с космических аппаратов (КА). Я не случайно уделила выше немало внимания сложности задачи рассеяния солнечного света в земной атмосфере и формирования поля яркости Земли, потому и столь значимо было открытие стратосферных аэрозольных слоев в атмосфере Земли, что подтвердило гипотезы о том, что атмосфера не только молекулярная, но и аэрозольная, что проявляется в непрерывных динамических процессах. Г.В.Розенберг не только первым сформулировал такую задачу, но и впервые реализовал теоретические построения в первом инструментальном исследовании земной атмосферы с ПКК. С борта ПКК «Восток-5» Валерий Федорович Быковский (14-19 июня 1963 г.) и ПКК «Восток-6» Валентина Владимировна Николаева-Терешкова (16-19 июня 1963 г.) провели фотосъемки сумеречного горизонта Земли. 17 июня 1963 года с борта ПКК были получены космонавтом первые в мире фотографические снимки края Земли с окружающим ее сумеречным 
и заревым ореолом, позволившие впервые установить и обосновать существование динамичных стратосферных аэрозольных слоев оптическими методами и средствами дистанционного зондирования с космических орбит.

Одна фотопленка оказалась настолько удачной, что после её обработки и имитационного физического моделирования в лабораторных условиях, организованного А.Б. Сандомирским, и математического моделирования, проведенного Т.А. Сушкевич, удалось впервые из космоса обнаружить стратосферные аэрозольные слои в атмосфере Земли и обосновать, что эти слои - следствие извержения вулкана Агунг на острове Бали, которое длилось почти год с середины февраля 1963 г. до 26 января 1964 г. Было положено начало инструментальным исследованиям оптически активных компонентов атмосферы с ПКК. Была показана высокая эффективность сумеречного метода ДЗ3 для исследования газовых и аэрозольных загрязнений атмосферы и релаксации аэрозольных стратосферных слоев вулканического происхождения.

Представительный обзор публикаций представлен в докторских диссертациях [66, 80-81] и книгах [82, 83]. Заслуживают внимания фундаментальные работы советских исследователей [84-102], свидетельствующие о глубине познания и понимания сложнейших атмосфернооптических процессов, до настоящего времени удивляющих своим разнообразием. Однако в последние десятилетия существенно снизился научный уровень сумеречных исследований и радиационных процессов в атмосфере из-за потери системных комплексных подходов, узкой специализации молодых поколений, которые не читают и не изучают труды предшественников, а в результате мелкотемье и частные результаты (что-то померили, что-то посчитали, ещё одна картинка-график и никаких существенных обоснований и выводов, только констатация факта), которые могут быть и не достоверными. Нет реальных условий для проведения сравнений, обобщений, серьезных дискуссий и обмена опытом (нынешний формат журнальных статей таких возможностей не предоставляет).

\section{4. Сферическая модель поля яркости атмосферы Земли и результаты первого научного эксперимента}

До начала космической эры сферические модели планетных атмосфер рассматривались в теории сумеречных явлений, в астрофизических исследованиях и в связи с проблемой лучистого теплообмена и равновесия. По мнению С.Чандрасекара [71], задача лучистого переноса в планетных атмосферах с учетом их сферичности анализировалась в работах W.McCrea (1928) [103], Н.А.Козырева (1934) [104], S.Chandrasekhar (1934) [105], L.Gratton (1937) [106]. Это были модели однородной консервативной сферы с изотропным рассеянием. Астрофизики предпочитали приближенные явные способы решения задач теории переноса излучения. Высокий математический 
уровень присущ работам советских астрофизиков: академика В.А.Амбарцумяна (18.09.1908-12.08.1996) [107], академика В.В.Соболева (02.09.1915-07.01.1999) $[108,109]$ и его учеников В.В.Иванова [110] и И.Н.Минина (1928-1999) [111]. Численные методы, разработанные и развитые Е.С.Кузнецовым (13.03.190117.02.1966) [26], Г.И.Марчуком (08.06.1925-24.03.2013) [112], К.С.Шифриным (26.07.1918-02.06.2011) [113], В.С.Владимировым (09.01.1923-03.11.2012) [114], позволили существенно усложнить сферические модели. Новые подходы разрабатывали Г.И.Марчук и Г.А.Михайлов - преимущественно метод МонтеКарло [115, 116], а также О.И.Смоктий [117] - полуаналитические методы, развитие наследия академиков В.В.Соболева и К.Я.Кондратьева (14.06.192001.05.2006).

Однако, реалистичные и наиболее приближенные к натурным условиям многомерные сферические модели, методы и численные алгоритмы расчета поля яркости Земли были созданы Т.А.Сушкевич [118-120] (Г.А.Михайлов и К.С.Шифрин были оппонентами по кандидатской диссертации [121], которая защищалась на диссертационном совете в Институте физики атмосферы АН СССР, председатель академик А.М.Обухов) и до сих пор никто в мире не превзошел эти уникальные результаты [122]. В США первая модель была построена Ж.Ленобль и З.Секера [123]. В этой модели сфера аппроксимировалась плоскими приближениями и модель не была реализована. Другие работы есть в обзоре Международной радиационной комиссии [124].

Задача состоит в определении интенсивности ослабленного прямого излучения от источников и стационарного поля интенсивности однократно и многократно рассеянного излучения в рассеивающей, поглощающей и излучающей сферической оболочке (атмосфере) с отражающей и излучающей подстилающей поверхностью (суша, океан, облака) или за её пределами [118, $120,122]$. Такая модель описывает радиационное поле Земли как планеты с атмосферой (кратко обозначение САЗ). Приближение стационарного поля физически корректно, поскольку исследуется процесс распространения солнечного или собственного излучения со скоростью света.

Полную интенсивность монохроматического (при фиксированном $\lambda$ или квазимонохроматического (при фиксированных $\lambda$ и $\Delta \lambda$ ) стационарного излучения в САЗ $\Phi_{\lambda}(\mathbf{r}, \mathbf{s})$, где индекс $\lambda$ - длина волны (ниже везде опускается), в точке $A(\mathbf{r})$ с радиус-вектором $\mathbf{r}$ в направлении $\mathbf{s}$ находим как решение общей краевой задачи теории переноса

$$
K \Phi(\mathbf{r}, \mathbf{s})=F^{i n},\left.\quad \Phi\right|_{t}=F^{t},\left.\quad \Phi\right|_{b}=\varepsilon R \Phi+F^{b}
$$

с линейными операторами: интегродифференциальный оператор записан как $K \equiv D-S$; дифференциальный оператор переноса

$$
D \equiv(\mathbf{s}, \operatorname{grad})+\sigma_{t o t}(\mathbf{r}),
$$

для двумерной сферической геометрии задачи с осевой симметрией 


$$
(\mathbf{s}, \nabla \Phi)=\cos \vartheta \frac{\partial \Phi}{\partial r}+\frac{\sin \vartheta \cos \varphi}{r} \frac{\partial \Phi}{\partial \psi}-\frac{\sin \vartheta}{r} \frac{\partial \Phi}{\partial \vartheta}-\frac{\sin \vartheta \sin \varphi \operatorname{ctg} \psi}{r} \frac{\partial \Phi}{\partial \varphi} ;
$$

интеграл столкновений - функция источника, описывающая многократное рассеяние,

$$
B(\mathbf{r}, \mathbf{s}) \equiv S \Phi=\sigma_{s c}(\mathbf{r}) \int_{\Omega} \gamma\left(\mathbf{r}, \mathbf{s}, \mathbf{s}^{\prime}\right) \Phi\left(\mathbf{r}, \mathbf{s}^{\prime}\right) d \mathbf{s}^{\prime}, \quad d \mathbf{s}^{\prime}=\sin \vartheta^{\prime} d \vartheta^{\prime} d \varphi^{\prime} ;
$$

оператор отражения в общем случае можно представить интегралом

$$
[R \Phi]\left(\mathbf{r}_{b}, \mathbf{s}\right)=\int_{\Omega^{-}} q\left(\mathbf{r}_{b}, \mathbf{s}, \mathbf{s}^{-}\right) \Phi\left(\mathbf{r}_{b}, \mathbf{s}^{-}\right) d \mathbf{s}^{-}, \mathbf{s} \in \Omega^{+} .
$$

Функция $F^{\text {in }}(\mathbf{r}, \mathbf{s})$ описывает источники излучения внутри сферической оболочки, например, собственное излучение; функции $F^{b}\left(\mathbf{r}_{b}, \mathbf{s}^{+}\right)$и $F^{t}\left(\mathbf{r}_{t}, \mathbf{s}^{-}\right)$источники излучения на границах сферической области, определенные для направлений внутрь сферической оболочки (в частности, это может быть внешний поток солнечного излучения и собственное излучение постилающей поверхности). Оператор $R$ описывает закон отражения излучения от подстилающей поверхности, расположенной на уровне нижней границы $\mathrm{r}_{b}$; параметр $0 \leq \varepsilon \leq 1$ фиксирует акт взаимодействия излучения с подстилающей поверхностью. Если $R \equiv 0$ (или $\varepsilon=0$ ), то имеем дело с первой краевой задачей теории переноса для сферического слоя с прозрачными, неотражающими, абсолютно "черными" границами или с "вакуумными" граничными условиями

$$
K \Phi_{a}=F^{i n},\left.\quad \Phi_{a}\right|_{t}=F^{t},\left.\quad \Phi_{a}\right|_{b}=F^{b}
$$

На основе имитационного моделирования, выполненного Т.А.Сушкевич, и анализа результатов космических фотографий сумеречного горизонта Земли, проведенного Г.В.Розенбергом, А.Б.Сандомирским и Т.А.Сушкевич, стратосферные аэрозольные слои были обнаружены впервые из космоса. В результате извержения вулкана Агунг гигантская пепловая колонна и раскаленный термик, поднявшиеся на высоты 19-26 км, явились источниками выноса аэрозолей в стратосферу, что привело к образованию стратосферного аэрозольного слоя, релаксация которого растянулась почти на два года.

ВПЕРВЫЕ результаты были опубликованы в новом советском академическом журнале "Физика атмосферы и океана" в 1965 году. На рис. 1 и рис. 2 приведены копии первых страниц этих публикаций. Это исторические документы, потому считаю необходимым их представить в настоящей статье в год 55-летнего юбилея научного открытия. 


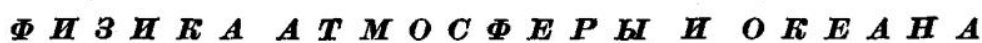

TOM 1965 № 4

УДК 551.593.55:629.195

\section{О СУМЕРЕЧНЫХ ИССЛЕДОВАНИЯХ ПЛАНЕТНЫХ АТМОСФЕР С КОСМИЧЕСКИХ КОРАБЛЕЙ}

\section{Г. В. РОЗЕНБЕРГ}

Выясняются возможности использования сумеречных условий для исследования планетных атмосфер в случае, когда наблюдатель находится на большой высоте.

Исследования света Солнца, рассеянного атмосферой планеты в сумеречных условиях, позволяют получить значительно больше сведений об оптической структуре атмосферы, чем исследования, выполняемые в дневных условиях. Это связано с тем, что сумеречные исследования могут быть распространены на значительно бо́льшие высоты п обеспечивают лучшеө высотное разрешение, чем дневные [1]. До сих пор теория сумеречного зондирования атмосферы развивалась только применительно к случаю, когда наблюдатель находится на земной поверхности. Между тем, если поместить наблюдателя на достаточно большой высоте над поверхностью планеты, в частности за пределами ее атмосферы, характер сумеречных явлений существенно изменяется, что открывает новые возможности для исследования строения атмосферы. Поскольку для выполнения сумереqных измерений могут быть использованы космические корабли, представляөт интерес рассмотреть әти возможности как с точки зрения исследования земной атмосферы, так и применительно к задаче исследования атмосфер других планет.

Рис. 1. Копия первой страницы из первой в мировой науке статьи о постановке задачи сумеречного зондирования горизонта Земли в условиях наблюдений с космического корабля [30]. 


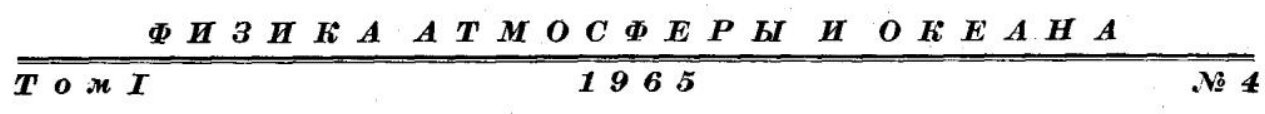

УдК 551.593 .55 .629 .195

\title{
СГРАТОСФЕРНЫЙ АЭРОЗОЛЬ ПО ИЗМЕРЕНИЯМ С КОСМИЧЕСКОГО КОРАБЛЯ
}

Г. В. РОЗЕНБЕРГ, В. В. НИКОЛАЕВА-ТЕРЕШКОВА

\begin{abstract}
На основе фотографий края Земли и ее сумеречного ореола, полученных с борта космического корабля "Восток-6», определена вертикальная структура аэрозольных слоев в стратосфере. Выявлены два аәрозоль-

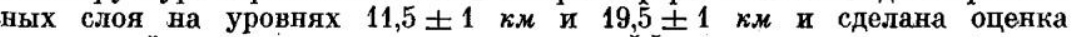
оптической толщины верхнего слоя и әффективного радиуса частиц. Проведено сравнение полученных результатов с даныыми аэростатных и самолетных измерений концентрации аэрозоля.
\end{abstract}

1. Когда космический корабль, находясь в области земной тени, приближается к терминатору, с его борта становится видимым световой ореол, поднимающийся над солнечной стороной горизонта. Размеры и яркость этого ореола, облекающего значительную часть остающегося в тени тела земного шара, увеличиваются по мере приближения к сумеречному поясу планеты. Нижняя часть ореола, непосредственно примыкающая к горизонту, окрашена в оранжевые цвета, постепенно переходящие по мере увеличения высоты над горизонтом сначала в белый, а затем в голубовато-синий цвет, сохраняющийся до напбольших высот, до которых прослеживается ореол.

Рис. 2. Копия первой страницы статьи [31] о сумеречном зондировании горизонта Земли в условиях наблюдений с космического корабля, в которой подтверждается обнаружение слоя Юнге в стратосфере и приведен первый в мировой науке фотоснимок стратосферного аэрозольного слоя (см. рис. 4). Обратите внимание на соавторов статьи.

На рис. 3 содержится оригинал схемы наблюдений сумерек с ПКК. ПЕРВЫЙ в мировой науке и практике фотоснимок сумеречного горизонта Земли с явно выраженными стратосферными аэрозольными слоями, полученный космонавтом с борта ПКК, представлен на рис. 4. На разрезе профиля яркости сумеречного горизонта, изображенного на рис. 5 , наглядно выражены вариации яркости в направлениях обнаружения стратосферных аэрозольных слоев. Подробный анализ постановки и результатов этого эксперимента содержится в статьях Г.В.Розенберга [30-31], посвященных этому уникальному научному открытию. 


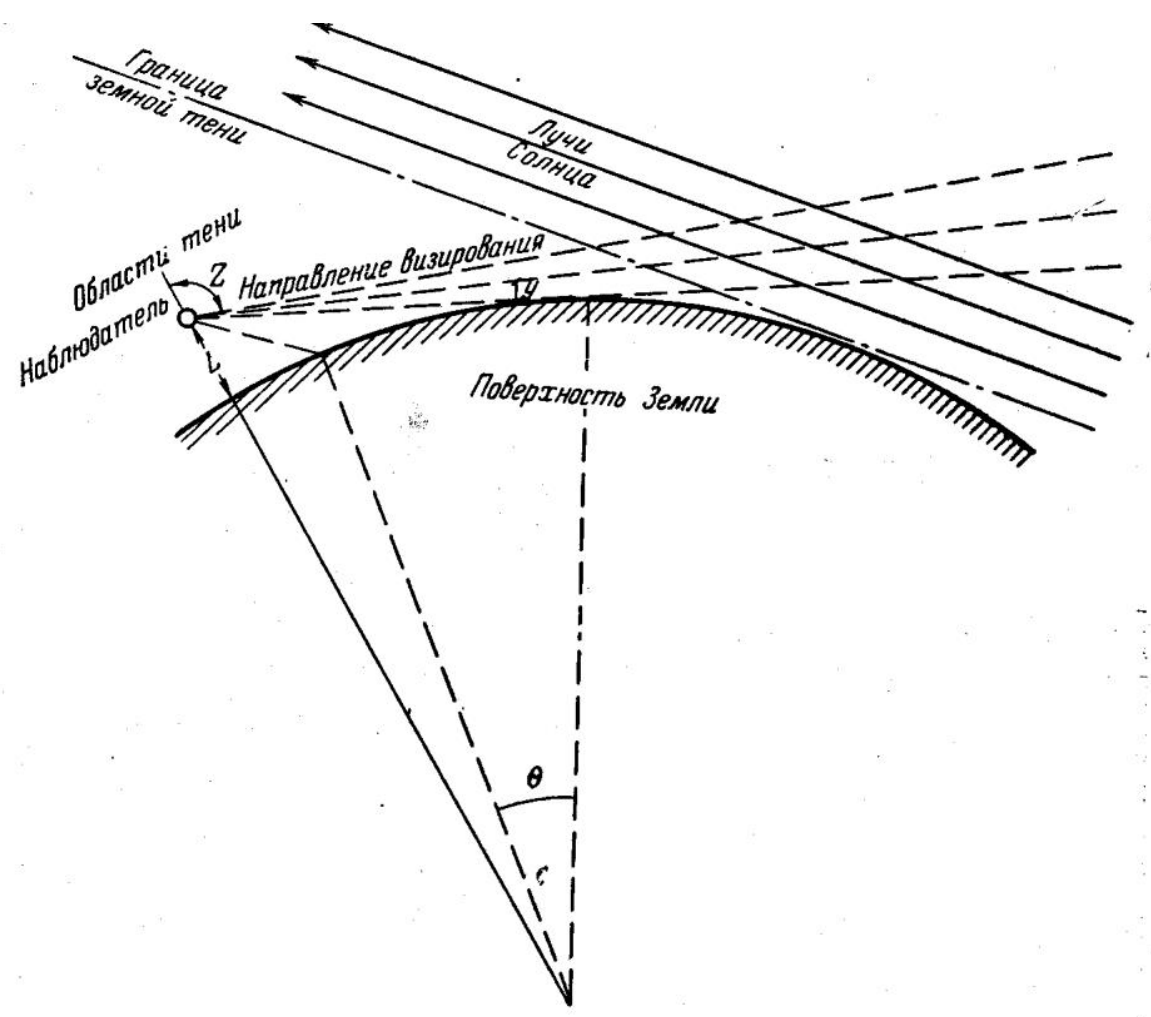

Рис. 3. Схема сумеречного зондирования с космического корабля. Оригинал рисунка Г.В.Розенберга из статьи [31].

Послесловие. С Г.В.Розенбергом автор сотрудничала со студенческих лет до последних дней жизни Г.В.Розенберга, с которым ушла и тайна этого открытия. Этой тайной владел и А.Б.Сандомирский, который разрабатывал аппаратуру для эксперимента и имитационного физического моделирования в лабораторных условиях. Георгий Владимирович поделился тайной с автором. В.Ф.Быковский и В.В.Николаева-Терешкова получили специальные фотокамеры $u$ по две специальные фотопленки. Кстати, обучал их Александр Константинович Городеикий из ИФА АН СССР, что сейчас в ИКИ РАН работает... Съемки сумеречного земного горизонта удалось провести только В.Ф.Быковскому, который был великолепно подготовлен физически (не случайно совершил три полета в космос!) и обладал уникальными способностями координации и ориентащии, что оказалось определяющим в июне 1963 года при полетах на кораблях «Восток», когда ещё не было надежных средств ориентации и стабилизации космического корабля и тем более космических часов и средств привязки по координатам к местности. После посадки обоих кораблей в один день 19 июня В.Ф.Быковский одну фотопленку подарил В.В.Николаевой-Терешковой $и$ именно на этой фотопленке запечатлен ПЕРВЫЙ снимок аэрозольных слоев из космоса (вторая фотопленка, что осталась у В.Ф.Быковского, оказалась засвеченной). Так В.В.Николаева-Терешкова стала соавтором открытия... 


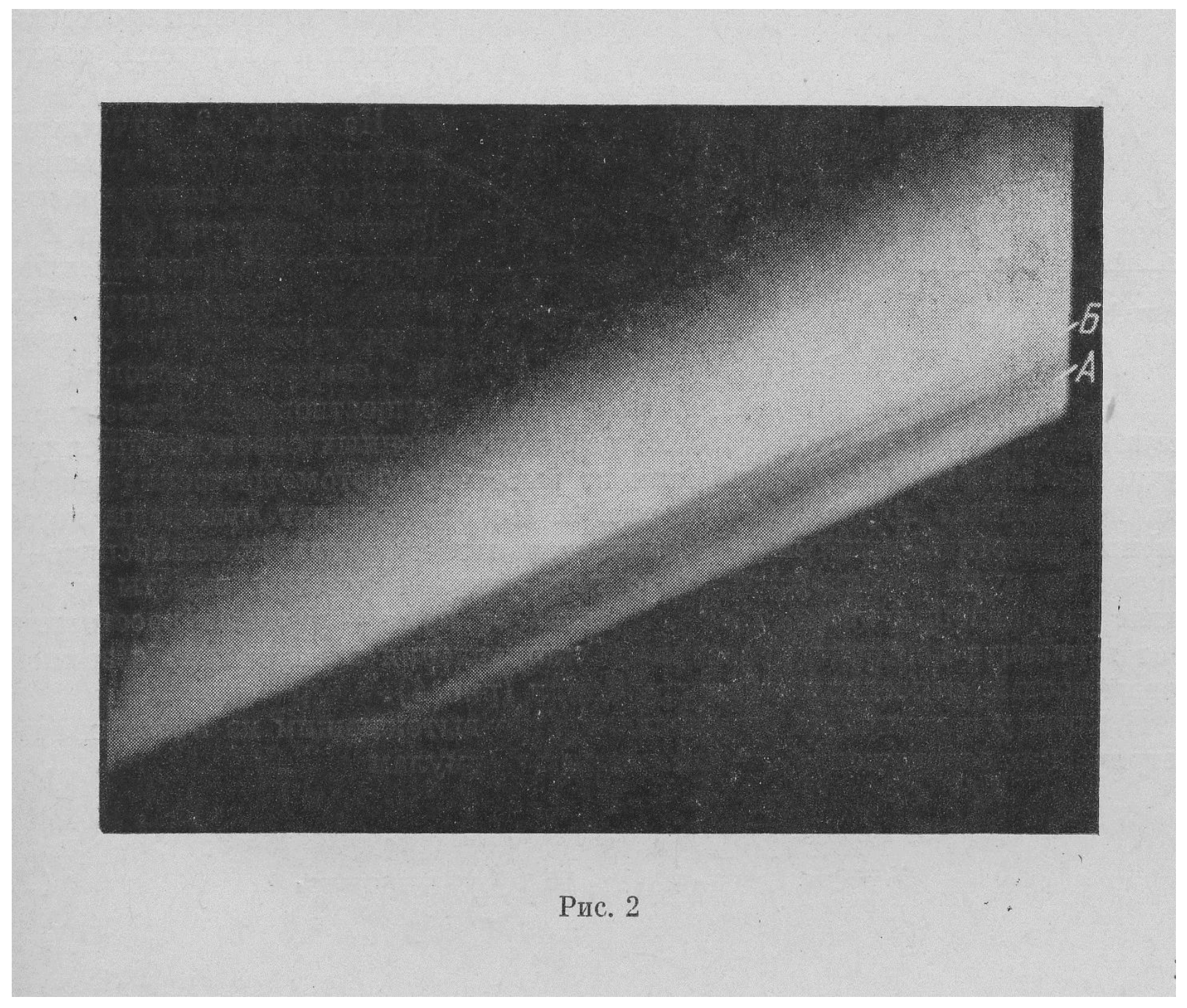

Рис. 4. Первый в мировой науке и практике фотографический снимок края Земли с окружающим её сумеречным ореолом, полученный с борта космического корабля «Восток» 17.VI.1963 г. Схема эксперимента изображена на рис. 3. Отчетливо выделяются две узкие полосы пониженной яркости (А и Б), свидетельствующие о существовании двух достаточно резко выраженных слоев повышенной мутности. Сохранена надпись «Рис. 2» из оригинала статьи Г.В.Розенберга [31]. 


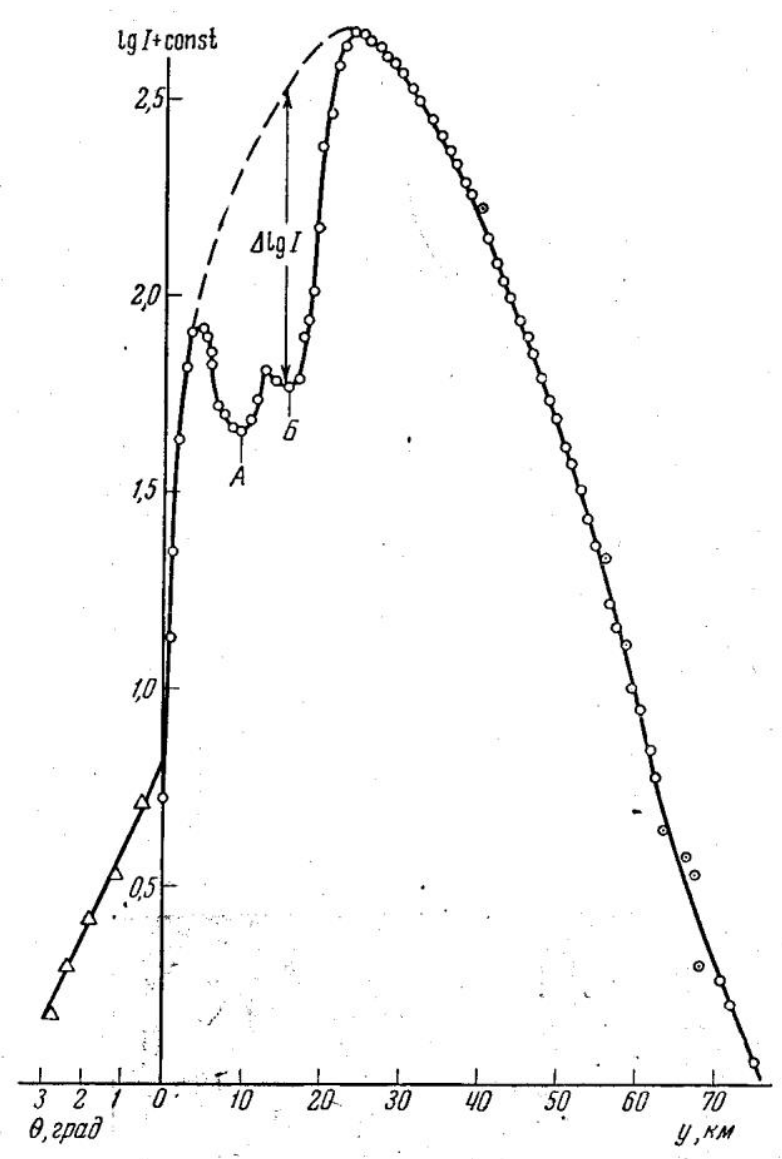

Рис. 5. Один из высотных фотометрических разрезов, полученных по фотографии рис. 4 , на котором наличие слоев повышенной мутности проявилось заметным снижением уровня яркости горизонта Земли.

\section{5. Заключение}

Космические атмосферно-оптические наблюдения, сопровождающиеся репрезентативным математическим моделированием, позволили не только обнаружить, но и впервые исследовать оптическую структуру и динамику стратосферных аэрозольных слоев методами дистанционного зондирования. Впервые результаты исследований стратификации и динамики изменений аэрозоля и озона в земной атмосфере с помощью оптического фотометрического дистанционного зондирования горизонта Земли с пилотируемых космических кораблей были получены экспериментально Г.В.Розенбергом и А.Б.Сандомирским с коллегами и с привлечением математического моделирования, проведенного Т.А.Сушкевич [10-14]. Публикации О.И.Смоктия [117] и Г.И.Марчука с Г.А.Михайловым [115, 116] в 1967 году явились первыми в мире открытыми публикациями по численному имитационному моделированию условий проведения космических фотосъемок и спектрографии зари и сумерек. В НАСА США приближенную сферическую 
модель разработала Ж.Ленобль [123], которая осталась только в теории. Из обзора международной Комиссии по радиации [124] со всей очевидностью следует преимущество и приоритет работ советских ученых по теории переноса излучения, которые обеспечивали приоритет СССР в космосе. Американские ученые своими наземными исследованиями последствий влияния извержения Агунг на состав атмосферы подтвердили открытие советских ученых [61, 62]. Важной роли аэрозольных слоев и вулканов в формировании климата посвящены монографии $[125,126]$.

В последние годы жизни академик Израэль Юрий Антониевич (15.05.193023.01.2014), основатель и первый директор Института глобального климата и экологии РАН, предлагал несколько сценариев спасения климата планеты и его управлением [127]. Ю.А.Израэль, будучи сопредседателем СоветскоАмериканской комиссии по сотрудничеству в области охраны окружающей среды, уделял большое внимание Рабочей Группе по изменению климата. Под редакцией Ю.А.Израэля и М.И.Будыко в 1987 году была опубликована монография коллектива авторов «Антропогенные изменения климата», которая в течение десятилетий была основным настольным пособием для ученых, работающих в этой области [128]. Ю.А.Израэлем опубликовано 27 научных монографии и более 300 научных статей. Девять монографий переведены на другие языки. Среди книг нужно отметить: «Мирные ядерные взрывы и окружающая среда» (1974), «Экология и контроль природной среды (1973, 1983), «Радиоактивные выпадения после ядерных взрывов и аварий» (1996); в соавторстве: «Кислотные дожди» (1983), «Глобальные климатические катастрофы» (1986), «Антропогенные изменения климата» (1987), «Антропогенная экология океана» (1989), «Чернобыль: радиоактивное загрязнение природной среды» (1990), «Озоновый земной щит и его изменения〉 (1992); второе дополненное издание на английском языке «Радиоактивное выпадение после ядерных взрывов и аварий» (2002), второе дополненное издание (совместно с А.В.Цыбань) «Антропогенная экология океана» $(2009$ г.). В 2007 г. в составе МГЭИК Ю.А.Израэль награжден Нобелевской премией мира. Премия была присуждена «за усилия по увеличению и распространению большего объема знания об антропогенном изменении климата и по созданию основ для мер, необходимых для противодействия таким изменением». Ю.А.Израэль - первый из крупных климатологов и единственный среди лидеров МГЭИК (Межправительственная группа экспертов по изменению климата), кто осознал бесполезность Киотского протокола в том виде, в котором его приняли в 1997 г. [128] (ввел термин «Климатгейт»), и немало сделал для подготовки «Парижского соглашения по климату» [129], подписанного более чем 190 странами членами ООН. Научное наследие Ю.А.Израэля огромно и значимо.

В последние десятилетия отмечена повышенная вулканическая активность. Последствия извержений вулканов могут носить локальный, региональный и глобальный характер. В соответствии с масштабами влияния действующих 
вулканов необходимо создавать локальный, региональный и глобальный мониторинг загрязнения воздушной среды. Период очищения воздушной среды от вулканических загрязнений зависит от особенностей извержений вулканов, состава газового и аэрозольного выбросов и высоты атмосферного столба над земной поверхностью, подверженного воздействию вулкана. Естественноприродные и антропогенные локальные и региональные загрязнения, которые влияют на климат [130] и образование осадков [131], можно исследовать и отслеживать с помощью наземных, аэровоздушных и ракетных средств мониторинга, включая наземные сумеречные методы, лазерное зондирование и оценивая спектральное пропускание прямых солнечных потоков. В масштабах планеты стратосферные аэрозольные слои следует наблюдать в течение всего периода их релаксации, а это может быть порядка двух лет, используя космические системы глобального мониторинга и зондирования. Сумеречный метод, представленный в данной публикации, с помощью фотометрических и спектральных средств по-прежнему остается ведущим. Кроме него разработаны методы зондирования по прямому солнечному потоку на горизонтальных трассах из космоса, но такие подходы сложнее в реализации.

В январе-марте 2018 года после 55-летнего спокойствия вновь началось извержение вулкана Агунг [46-48, 132] на острове Бали, а в апреле заметно похолодание даже на территории Евразии.

3-4 мая 2018 года на крупнейшем острове штата Гавайи образовалось несколько трещин на поверхности земли, из которых шли лава и пар. Так началось «страшное» мощное извержение вулкана Килауэа [132]. Ему предшествовали землетрясения. Не сбылись предсказания вулканологов: «Что касается природных последствий, то оптимистические прогнозы. ... ни потепления или похолодания, ни затмения солнцуа или кислотных дождей не будет, так как в данном случае происходит гавайский тип извержения, когда в атмосферу выбрасывается минимальное количество пепла, то есть можно находиться недалеко от лавового потока и спокойно дышать. Тем более нет смысла опасаться по поводу каких-нибудь тектонических изменений: Гавайские острова под воду не уйдут». Через пять недель продолжающегося извержения пошел «ледяной дождь» и часть острова оледенела. В июне на острове отмечено резкое похолодание - извержение вызвало аномальные холода на Гавайях. Температура заметно понизилась в разных регионах планеты. Возникла природная аномалия, которая поставила ученых в тупик, так как ничего подобного до сих пор не фиксировалось... Это задачи для ученых...

Особую признательность хочу выразить Матвею Семеновичу Малкевичу из Института физики атмосферы АН СССР (позже перешел с лабораторией в Институт космических исследований АН СССР), ученика Е.С.Кузнецова и математика по образованию, с которым проходило тесное сотрудничество по стратегическим задачам космических исследований на основе математического моделирования и многофакторной обработки космических данных [23-25]. 
К столетию Г.В.Розенберга 21-24 октября 2014 года в Институте физики атмосферы им. А.М.Обухова прошла Международная конференция «Аэрозоль и оптика атмосферы», на которой многочисленные участники напомнили о важном вкладе ВЕЛИКОГО УЧЕНОГО - ПЕРВООТКРЫВАТЕЛЯ и ЭНЦИКЛОПЕДИСТА - в науки о Земле и «Будущем Земли» [133]. Г.В.Розенберг один из первых обратил особое внимание на атмосферные и морские аэрозоли и фактически сформировал уникальное направление в науке «оптика аэрозолей», которое активно развивается и до сих пор не видно конца этим исследованиям, поскольку столь велико их разнообразие и влияние не только на природные среды и климат, но и на человека. Что касается сумеречного метода, то на эту тему «Особенности поляризации света, рассеянного атмосферой в условиях сумеречного освещения〉 Г.В.Розенберг защитил кандидатскую диссертацию ещё в 1946 году, включая и эффекты поляризации излучения, которые только что начинали постигать [134].

Работа выполнена при поддержке Российского фонда фундаментальных исследований (проекты 18-01-00609 a, 17-01-00220 a).

\section{Список литературы}

1. Сушкевич Т.А. Главный Теоретик М.В.Келдыш и Главный Конструктор космонавтики С.П.Королев - покорители космоса // Современные проблемы дистанционного зондирования Земли из космоса. 2011. Т. 8. № 1. С. 9-25. http://jr.rse.cosmos.ru/article.aspx?id=819

2. Попов Ю.П. 50-летие Института прикладной математики имени М.В.Келдыша. 2003. http://www.keldysh.ru/grants/rffi//50_years/; ИПМ им. М.В. Келдыша PAH http://keldysh.ru/httpd/kiam-info_fr.html.

3. Прикладная небесная механика и управление движением. Сборник статей, посвященный 90-летию со дня рождения Д.Е.Охоцимского / Составители: Т.М.Энеев, М.Ю.Овчинников, А.Р.Голиков. // Труды ИПМ им. М.В. Келдыша РАН. М.: ИПМ им. М.В. Келдыша, 2010. 368 с. http://keldysh.ru/memory/okhotsimsky/index.htm

4. Сушкевич Т.А. М.В.Келдыш - организатор международного сотрудничества в космосе и первой советско-американской Программы «СоюзАполлон» (ЭПАС) // Современные проблемы дистанционного зондирования Земли из космоса. 2011. Т. 8. № 4. С. 9-22.

http://jr.rse.cosmos.ru/article.. spx $? \mathrm{id}=930$

5. Sushkevich T.A. Solar and Terrestrial Radiation Research in Newly Independent States: a Review // Proceedings of the International Radiation Symposium IRS'96: Current Problems in Atmospheric Radiation, Fairbanks, Alaska, USA, August 19-24, 1996. Hampton, Virginia, USA: A.DEEPAK Publishing, 1997. P. 1021-1024.

6. Сушкевич Т.А. О решении задач атмосферной коррекции спутниковой информации // Исслед. Земли из космоса. 1999. № 6. С. 49-66. 
7. Сушкевич T.A., Максакова С.В. Обзор методов учета земной поверхности и задачах дистанционного зондирования в расчетах радиационного поля Земли - 2 // Препринты ИПМ им. М.В.Келдыша. 1999. № $52.32 \mathrm{c}$.

8. Сушкевич Т.А., Максакова С.В. Обзор методов учета земной поверхности и задачах дистанционного зондирования в расчетах радиационного поля Земли - 3 // Препринты ИПМ им. М.В.Келдыша. 1999. № $53.32 \mathrm{c}$.

9. Сушкевич Т.А., Максакова С.В. Обзор методов учета земной поверхности и задачах дистанционного зондирования в расчетах радиационного поля Земли - 4 // Препринты ИПМ им. М.В.Келдыша. 1999. № $54.32 \mathrm{c}$.

10. Сушкевич T.A. O пионерских работах по математическому моделированию радиационного поля Земли при освоении космоса // Современные проблемы дистанционного зондирования Земли из космоса. 2008. Вып. 5. Том 1. C. 165-180. http://jr.rse.cosmos.ru/article.aspx?id=393

11. Сушкевич T.А. К истории первого научного эксперимента по дистанционному зондированию Земли на пилотируемом космическом корабле // Современные проблемы дистанционного зондирования Земли из космоса. 2008. Вып. 5. Том 1. С. 315-322. http://jr.rse.cosmos.ru/article.aspx?id=415

12. Sushkevich T.A. Pioneering remote sensing in the USSR. 1. Radiation transfer in the optical wavelength region of the electromagnetic spectrum // International Journal of Remote Sensing. Special Issue: The Remote Sensing Heritage of Academician Kirill Ya. Kondratyev. 2008. V. 29. № 9. P 2585-2597.

13. Sushkevich T.A. Pioneering Remote Sensing in the USSR. 2. Global spherical models of radiation transfer // International Journal of Remote Sensing. Special Issue: The Remote Sensing Heritage of Academician Kirill Ya. Kondratyev. 2008. V. 29. № 9. P 2599-2613.

14. Sushkevich T.A. Pioneering Space Research in the USSR and Mathematical Modelling of Large Problem of Radiation Transfer // Physics of Particles and Nuclei Letters. 2011. V. 8. № 5. 3. 441-450. Pleiades Publishing, Ltd., 2011. ISSN 15474771.

15. Сушкевич T.A. Космические проекты: информационноматематический аспект и супервычисления (история и перспективы) // Вестник Южно-Уральского государственного университета (серия Математическое моделирование и программирование). 2011. Выпуск 8. № 17 (234). С. 4-19. ISSN 2071-0216.

16. Сушкевич Т.А., Стрелков С.А., Максакова С.В. 60 лет от первого совещания по ИСЗ до современных систем дистанционного зондирования и мониторинга Земли из космоса: информационно-математический аспект (история и перспективы) // Оптика атмосферы и океана. 2014. Т. 27 . № 7. C. 573-580. ISSN 0869-5695. http://ao.iao.ru/ru/content/vol.27-2014/iss.07/2 
17. Железняков А.Б. Секреты американской космонавтики. Почему американцы были вторыми в космосе. Серия: Люди в космосе. М.: Издательство «Эксмо», 2012. 528 с. ISBN 978-5-699-48759-2. Литагент «Эксмо» https://document.wikireading.ru/23965

18. Обухов А.М. Турбулентность и динамика атмосферы. Л.: Гидрометеоиздат, 1988. 414 с. ISBN: 5-286-00059-2. http://bookre.org/reader?file $=480897$

19. Турбулентность, динамика атмосферы и климата. Труды Международной конференции, посвященной памяти академика А.М.Обухова / Отв. ред. Г.С.Голицын, И.И.Мохов, С.Н.Куличков, О.Г.Чхетиани. М.: ГЕОС, 2014. $696 \mathrm{c}$.

20. Турбулентность, динамика атмосферы и климата. 100-летие со дня рождения А.М.Обухова. Международная конференция «Турбулентность, динамика атмосферы и климата», 16-18 мая 2018, ИФА РАН имени A.М.Обухова. http://www.ifaran.ru/science/conferences/Obukhov100.html; http://www.ras.ru/news/shownews.aspx?id=a28b5b78-d29f-434b-bdb1eb691918b16e

21. Фейгельсон Е.М., Малкевич М.С., Коган С.Я., Коронатова Т.Д., Глазова К.С., Кузнецова М.А. Расчет яркости света в атмосфере при анизотропном рассеянии. Часть $1 / /$ Труды Института физики атмосферы АН СССР. № 3. М.: Изд-во АН СССР, 1958. $101 \mathrm{c}$.

22. Атрошенко В.С., Глазова К.С., Малкевич М.С., Фейгельсон Е.М. Расчет яркости света в атмосфере при анизотропном рассеянии. Часть 2 // Труды Института физики атмосферы АН СССР. № 3. М.: Изд. АН СССР, 1962. 223 с.

23. Малкевич М.С. Оптические исследования атмосферы со спутников. Доктор. диссертация физ.-мат. наук. Автореферат. М., 1971. 22 с.

24. Малкевич М.С. Оптические исследования атмосферы со спутников. М.: Наука, 1973. 303 с.

25. Космическая стрела. Оптические исследования атмосферы / Под ред. А.М.Обухова и В.М.Ковтуненко. М.: Наука, 1974. 327 с.

26. Кузнецов Е.С. Избранные научные труды (в связи со 100-летием со дня рождения) / Ответ. ред. и состав. Сушкевич Т.А. М.: ФИЗМАТЛИТ, 2003.784 с. (при поддержке РФФИ)

27. Розенберг Г.В. О новом явлении в рассеянном свете сумеречного неба // Докл. АН СССР. 1942. Т. 36. № 9. С. 288-293.

28. Розенберг Г.В. Сумеречные явления, их природа и использование для исследования атмосферы // Успехи физических наук. 1963. Т. 79, вып. 3. С. 441552. DOI: 10.3367/UFNr.0079.196303b.0441, https://ufn.ru/ru/articles/1963/3/b/

29. Розенберг Г.В. Сумерки. М.: ГИФМЛ, 1963.380 с.

30. Розенберг Г.В. О сумеречных исследованиях планетных атмосфер с космических кораблей // Известия АН СССР. Физика атмосферы и океана. 1965. T. 1. № 4. С. 377-385. 
31. Розенберг Г.В., Николаева-Терешкова В.В. Стратосферный аэрозоль по измерениям с космического корабля // Известия АН СССР. Физика атмосферы и океана. 1965. Т. 1. № 4. С. 386-394.

32. 75 лет ИЗМИРАН (1939-2014). 2014. http://www.izmiran.ru/info/izmiran75/session/IZMIRAN-75-slides.pdf

33. Вернов С.Н., Григоров Н.Л., Логачев Ю.И., Чудаков А.Е. Измерение космического излучения на искусственном спутнике Земли // Доклады АН CCCP. 1958. T. 120. № 6. С. 1231-1233.

34. Вернов С.Н., Вакулов П.В., Горчаков Е.В., Логачев Ю.И., Чудаков А.Е. Изучение мягкой компоненты космических лучей за пределами атмосферы // Искусственные спутники Земли. 1958. Т. 1, вып. 2. С. 61-69.

35. Вернов С.Н., Чудаков А.Е. Исследование космических лучей и земного корпускулярного излучения при полетах ракет и спутников // Успехи физических наук. 1960. Т. 70. № 4. C. 585-619. https://ufn.ru/ru/articles/1960/4/b/

36. Масленников М.В., Сигов Ю.С., Сушкевич Т.А. Численное решение задачи о стационарном обтекании тела разреженной плазмой // В сб.: Тезисы докладов. Четвертое совещание по магнитной гидродинамике, Рига, 22-27 июня 1964 г. Рига: Изд. АН Латвийской ССР, 1964.

37. Масленников М.В., Сигов Ю.С. Дискретная модель вещества в задаче об обтекании тел разреженной плазмой // Доклады АН СССР. 1964. Т. 159. № 5. C. 1013-1016.

http://www.mathnet.ru/php/archive.phtml?wshow=paper\&jrnid=dan\&paperid=30654 \&option_lang=rus

38. Сушкевич Т.А. К 50-летию первой отечественной полупроводниковой ЭВМ «Весна» и отечественной компьютерной графики // Труды XVI Международной суперкомпьютерной конференции «Научный сервис в сети Интернет: многообразие суперкомпьютерных миров» (г. Новороссийск, АбрауДюрсо, 22-27 сентября 2014 г.). Российская академия наук, Суперкомпьютерный консорциум университетов России. М.: Издательство Московского университета им. М.В.Ломоносова, $2014 . \quad$ С. 122-125. http://agora.guru.ru/abrau2014/pdf/122.pdf

39. Розенберг Г.В., Пылдмаa В.К. Некоторые результаты сумеречного зондирования атмосферы и изучения его возможностей // Известия АН СССР. Физика атмосферы и океана. 1966. Т. 2. № 8. С. 820-832.

40. Дривинг А.Я., Михайлин И.М., Розенберг Г.В., Сандомирский А.Б., Трифонова Г.И. Фотометрический анализ снимков ореола зари, полученных с космического корабля «Восток-6» // Известия АН СССР. Физика атмосферы и океана. 1966. Т. 2. № 10. С. 1046-1054.

(Driving, A., Mikhailin, I. M., Rosenberg, G. V., Sandomerskii, A. B., TRIFonova, G. I.: 1966, 'Photometric Analysis of Photographs of the Twilight Aureole Obtained from the Spaceship "Vostok-6", Izv. Atmospheric and Oceanic Phys. 2 (10), 1046-1054, перевод. издание на англ.языке). 
41. Розенберг Г.В. Оптические исследования атмосферного аэрозоля // Успехи физических наук. 1968. Т. 95 . № 1. С. 159-208. DOI: 10.3367/UFNr.0095.1968051.0159; https://ufn.ru/ru/articles/1968/5/1/

42. Розенберг Г.В., Сандомирский А.Б. Оптическая стратификация атмосферного аэрозоля // Известия АН СССР. Физика атмосферы и океана. 1971. T. 7. № 7. С. 737-749.

43. Розенберг Г.В., Сандомирский А.Б., Сушкевич Т.А., Альтовская Н.П. Поле яркости зари, наблюдаемой с космических кораблей // Известия АН СССР. Физика атмосферы и океана. 1971. Т. 7. № 3. С. 279-290.

44. Розенберг Г.В., Сандомирский А.Б., Сушкевич Т.А., Альтовская Н.П. Некоторые результаты фотометрических исследований дневного горизонта Земли с космических кораблей «Союз-4» и «Союз-5» // Известия АН СССР. Физика атмосферы и океана. 1971. Т. 7. № 6. С. 590-598.

45. Розенберг Г.В., Сандомирский А.Б., Сушкевич Т.А., Матешвили Ю.Д. Исследование стратификации аэрозоля в стратосфере по программе «СоюзАполлон» // Известия АН СССР. Физика атмосферы и океана. 1980. Т. 16. № 8. C. 861-864.

46. Алексеенко А., Любимова Н. Вулкан Агунг сегодня. Последние новости с Бали. http://life-with-dream.org/agung-news/

47. Малышева Ксения. Вулкан Агунг на Бали выбросил 9-километровый столб дыма и пепла. https://naked-science.ru/article/sci/vulkan-agung-na-balivybrosil-9

48. Ивлиева О.В., Аманах Ю.Ю. Современная деятельность вулкана Агунг на Бали. http://www.scienceforum.ru/2018/2904/2144

49. Любимова Наталия. Извержение вулкана Агунг в 1963 году. Хронология событий, рассказы очевидцев. http://life-with-dream.org/gunungagung-1963/

50. Фесенков В.Г. О строении атмосферы (фотометрический анализ сумерек) // Труды Главной Российской астрофизической обсерватории. 1923. Т. 2. C. 7-123.

51. Фесенков В.Г. К исследованию стратосферы путем фотометрического анализа сумерок // Известия Академии наук СССР. VII серия. Отделение математических и естественных наук. 1934. № 10. С. 1501-1515. http://mi.mathnet.ru/izv4981; http://mi.mathnet.ru/rus/izv/y1934/i10/p1501

52. Мегрелишвили Т.Г. Закономерности вариаций рассеянного света и излучения сумеречной атмосферы Земли. Тбилиси: Мецниереба, 1981. 276 с.

53. Rimmer W.B. The depletion of solar radiation by volcanic dust // Gerl. Beitr. Geophys. 1937. V. 50. P. 388-393.

54. Junge C.E. Sulfur in the atmosphere // J. Geophys. Res. 1960. V. 65. № 1. P. 227-237.

55. Junge C.E., Chagnon C.W., Manson J.E. Stratospheric aerosols // J. Meteorol. 1961. V.18. P. 81-108. 
56. Junge C.E. Vertical profiles of condensation nuclei in the stratosphere // J. Meteorol. 1961. V.18. P. 501-509.

57. Chagnon C.W., Junge C.E. The vertical distributions of submicron particles in to stratosphere // J. Meteorol. 1961. V. 18. P. 746-752

58. Junge C.E., Chagnon C.W. Stratospheric aerosols studies // J. Geophys. Res. 1961. V. 66. № 7. P. 2163-2182.

59. Junge Christian E. Air Chemistry and radioactivity. International Geophysics Series. 1963. Volume 4. Academic Press, New York, London, 1963. 385 p. (Юнге Христиан Е. Химический состав и радиоактивность атмосферы / Пер. с англ. В.Н.Петрова и А.Я.Прессмана; под ред. Ю.А.Израэля. М.: Изд-во «Мир», 1965. 425 с.)

60. Volz F.E., Goody R.M. The intensity of the twilight and upper atmospheric dust // J. Atmospheric Sci. 1962. V. 19. № 5. P. 385-406.

61. Volz F.E. Twilight Phenomena Caused by the Eruption of Mt. Agung Volcano // Science. 1964. V. 144. P. 1121-1122.

62 . Volz F.E. Note on the global variation of stratospheric turbidity since the eruption of Agung volcano // Tellus. 1965. V. 17. P. 513-515.

63. Розенберг Г.В. Тайна вечерней зари // Научно-познавательный журнал «Познавайка». http://www.poznavayka.org/astronomiya/tayna-vecherney-zari/

64. Ibn al-Haytham. The optics of Ibn al-Haytham, in 7 books / Transl. with introd. and Comm. by A.I.SABRA. London: The Warburg Institute University of London, 1989. (Аль-Хайтам. Аль-Хайтам Оптика. В 7 книгах: 1) О зрении и о глазе, 2) О распространении света, 3) Об ошибках зрения, 4) Об отражении от зеркальных поверхностей, 5) О воображении, 6) Об ошибках зрения при отражении от плоских, цилиндрических и конических зеркалах, 7) О преломлении света и об ошибках зрения при преломлении.)

65. Kepler Johann. De Vitellionem paralipomena, quibus astronomiae pars optica traditur. Frankfurt, 1604; Kepler Johann. Dioptrica. Frankfurt, 1611; перепечатана London, 1653. (Кеплер Иоганн. Паралипомены к Вителлию. В книге «Дополнения к Вителлию или Оптическая часть астрономии». Дополнение к Вителлию, 1604; Диоптрика, 1611).

https://www.syl.ru/article/282312/new_kepler-iogann-biografiya-foto-i-interesnyiefaktyi

66. Смеркалов В.А. Прикладная оптика атмосферы. Диссертация доктора техн. наук. Санкт-Петербург, 1997. 334 с.

67. Микиров А.Е., Смеркалов В.А. Исследование рассеянного излучения верхней атмосферы Земли. Л.: Гидрометеоиздат, 1981. $208 \mathrm{c.}$

68. Миннарт М. Свет и цвет в природе / Ред. пер. с англ. Г.А.Лейкин. М.: Государственное издательство физико-математической литературы, 1958. 424 с. http://www.klex.ru/ru 
69. Gruner Paul, Kleinert Heinrich. Die Dämmerungserscheinungen // In Probleme der Kosmischen Physik. Bd. X. Hamburg: Henri Grand, 1927. 124 p. (Сумеречные явления)

Gruner P. Dämmerungserscheinungen // In Handbuch der Geophysik. 1942. Bd. VIII. Bornträger, Berlin. P. 432-526.

Gruner P. Dämmerungserscheinungen // In Handbuch der Geophysik (ed. by F.Linke and F.Moller). 1958. V. VIII. Borntrager, Berlin. P. 432-526. http://ru.booksc.org/book/5542375/0498ab

70. Link F. Sondages de la haute atmosphere a j'aide des phenomenes crepuscularies // J. observ. 1934. V. 17. P. 161-180.

71. Chandrasekhar S. Radiative Transfer. London: Oxford, Clarendon Press, 1950. 405 р. (Чандрасекар Субраманьян. Перенос лучистой энергии / Пер. с англ. издания под ред. Е.С. Кузнецова. М.: Издательство иностранной литературы, 1953. 432 с.)

72. Штауде Н.М. Фотометрические наблюдения сумерек как метод изучения верхней стратосферы. Труды комиссии по изучению стратосферы при АН СССР. Т. 1. М.-Л.: АН СССР, 1936. 162 с.

73. Штауде Н.М. Фотометрические наблюдения сумерек, как метод изучения верхней стратосферы. Диссертация кандидата физ.-мат. наук. Автореферат. 23.03.1945, Обсерватория АН Казахской ССР, Алма-Ата.

74. Штауде Н.М. Вторичное рассеяние во время сумерек при разных строениях атмосферы // Доклады АН СССР. 1949. Т. 64. № 6. С. 819-822.

75. Штауде Н. М. Теория сумерек. Автореферат диссертации на соискание ученой степени доктора физ.-мат. наук. Геофизический институт АН CССР, Москва. 1950. 5 с. (защита не состоялась) https://search.rsl.ru/ru/record/01006056792

76. Штауде Н.М. Автобиография. На рубежах познания Вселенной. Историкоастрономические исследования. Т. XXII. М.: Наука, 1990. С. 395-466.

77.Хвостиков И.А. Свечение ночного неба // Успехи физических наук. 1937. T. 17. C. 121-174. DOI: 10.3367/UFNr.0017.193702a.0121;

URL: https://ufn.ru/ru/articles/1937/2/a/

78. Хвостиков И.А. Свечение ночного неба / Отв. ред. С.И.Вавилов. М.-Л: Издательство Академии наук СССР, 1937. 165 с. (Серия научно-популярная). ISBN: 978-5-458-28331-1.

79. Хвостиков И.А. Теория рассеяния света и ее применение к вопросам прозрачности атмосферы и туманов // Успехи физических наук. 1940. Т. 24, вып. 2. C. 165-227. DOI: 10.3367/UFNr.0024.194006a.0165;

URL: https://ufn.ru/ru/articles/1940/6/a/

80. Кальсин А.В. Методы и средства зондирования средней и верхней атмосферы Земли. Диссертация кандидата физ.-мат. наук. Обнинск, 2002. 206 с.

81. Поляков А.В. Определение газового состава атмосферы и характеристик аэрозоля затменным методом. Диссертация доктора физ.-мат. наук. Санкт-Петербург, 2006. 373 с. 
82. Ивлев Л.С., Андреев С.Д. Оптические свойства атмосферных аэрозолей. Л.: Изд-во ЛГУ, 1986. 359 с.

83. Креков Г.М., Рахимов Р.Ф. Оптические модели атмосферного аэрозоля. Томск: Изд-во Томского филиала СО АН СССР, 1986. 294 с.

84. Розенберг Г.В., Хвостиков И.А., Юдалевич Ф.Ф. О роли вторичного рассеяния в сумерки // Доклады АН СССР. 1948. Т. 64. № 6. С. 819-823.

85. Юдалевич Ф.Ф. К вопросу о роли вторично рассеянного света // Доклады АН СССР, 1947. Т. 55. № 8. С. 717-720.

86. Юдалевич Ф.Ф. Основы теории сумеречных явлений с учетом влияния вторичного рассеяния света в атмосфере // Известия АН СССР. Серия геогр. и геофиз. 1950. Т. 14. № 6. С. 562-570.

87. Юдалевич Ф.Ф. О построении теории сумеречных явлений с учетом вторичного рассеяния // Доклады АН СССР. 1950. Т. 75. № 6. С. 799-802.

88. Мегрелишвили Т.Г. О границах применимости сумеречного метода исследования атмосферы // Известия АН СССР. Серия геофиз. 1956. № 8. С. 976-984.

89. Фесенков В.Г. К теории яркости дневного неба при сферической Земле // Астроном. журн. 1955. Т. 32. № 3. С. 265-274.

90. Фесенков В.Г. Сумерки как метод исследования атмосферы // Известия Астрофиз. ин-та АН КазССР. 1961. Т. 12. С. 3-20.

91. Фесенков В.Г. О сумеречном методе исследования оптических свойств атмосферы // Труды Астрофиз. ин-та АН КазССР. 1962. Т. 3. С. 214-230.

92. Фесенков В.Г. О рассеянии высших порядков в зените сумеречного неба // Доклады АН СССР. 1967. Т. 174. № 4. С. 833-836.

93. Фесенков В.Г. О зондировании оптических свойств атмосферы при помощи искусственных спутников // Астроном. журн. 1967. Т. 44, № 1. С. 3-10.

94. Фесенков В.Г. К вопросу об исследовании сумеречных явлений // Атмосферная оптика. М.: Наука, 1968. С. 96-106.

95. Фесенков В.Г. О методе исследования сумеречных явлений // Атмосферная оптика. М.: Наука, 1968. С. 175-200.

96. Дивари Н.Б., Плотникова Л.И. Вычисленные яркости сумеречного неба // Астроном, журн. 1965. Т. 42. № 5. С. 1090.

97. Дивари Н.Б. Высота сумеречного луча // Атмосферная оптика (Труды совещаний по атмосферной оптике комиссии по оптической нестабильности земной атмосферы Астросовета АН СССР. Пулково, ноябрь-декабрь 1965 г. и декабрь 1966 г. АН СССР, Астрономический совет). М.: Наука, 1968. С. 105116.

98. Дивари Н.Б. О некоторых особенностях сумеречного свечения // Атмосферная оптика (Труды Совещания по атмосферной оптике Рабочей группы по оптической нестабильности земной атмосферы Астросовета $\mathrm{AH}$ СССР. Ужгород, 8-10 октября 1968 г. АН СССР, Астрономический совет). М.: Наука, 1970. С. 158-165. 
99. Дивари Н.Б. Об определении концентрации атмосферной пыли и ее индикатрисы рассеяния по яркостям первичных сумерек // Бюлл. Абастуманской астрофиз. обсерв. 1972. № 41. С. 87-99.

100. Дивари Н.Б. Методы и результаты определения рассеивающих свойств атмосферы в условиях сумерек // Пыль в атмосфере и околоземном космическом пространстве. М.: Наука, 1972. С. 75-90.

101. Морозов В.М. О некоторых особенностях однократно рассеянного света в сумерки // Известия АН СССР. Физика атмосферы и океана. 1966. Т. 2. № 8. С. 835-847.

102. Микиров А.Е., Львова А.А. Оценка пылевой составляющей верхней атмосферы сумеречным методом // Атмосферная оптика (Труды совещаний по атмосферной оптике комиссии по оптической нестабильности земной атмосферы Астросовета АН СССР. Пулково, ноябрь-декабрь 1965 г. и декабрь 1966 г. АН СССР, Астрономический совет). М.: Наука, 1968. С. 114-125.

103. McCrea W. // Monthly Notices of the Royal Astronomical Society. 1928. V. 88. P. 729. http://www.ras.org.uk

104. Козырев H.A. // Monthly Notices of the Royal Astronomical Society. 1934. V. 94. P. 430. http://www.ras.org.uk

105. Chandrasekhar S. // Monthly Notices of the Royal Astronomical Society. 1934. V. 94. P. 444. http://www.ras.org.uk

106. Gratton L. // Soc. Astron. Italiana. 1937. V. 10. P. 309

107. Амбарцумян B.А. Теория рассеяния света // Научные труды. Т. I. Ереван: Изд-во АН АрмССР, 1960. С. 169-290. (Ambartsumyan V.A. "Theory of light scattering" // Scientific works. Vol. 1, Yerevan: Publishing House of the Academy of Sciences of the Armenian SSR, 1960. P. 169-290).

108. Соболев В.В. Перенос лучистой энергии в атмосферах звезд и планет. М.: Изд-во ГИТТЛ, 1956. $391 \mathrm{c.}$

109. Соболев В.В. Рассеяние света в планетных атмосферах. М.: Наука, 1972. $335 \mathrm{c}$.

110. Иванов В.В. Перенос излучения и спектры небесных тел. М.: Наука, 1969. $472 \mathrm{c}$.

111. Минин И.Н. Теория переноса излучения в атмосферах планет. М.: Наука, 1988. 264 с.

112. Марчук Г.И. Численные методы расчета ядерных реакторов. М.: Атомиздат, $1958.381 \mathrm{c}$.

113. Шифрин К.С. Рассеяние света в мутной среде. М.-Л.: Гостехиздат, $1961.288 \mathrm{c}$.

114. Владимиров В.С. Математические задачи односкоростной теории переноса частиц // Труды МИАН им. В.А.Стеклова. Вып. LXI (61). М.: Изд-во AH CCCP, 1961. 158 c.

115. Марчук Г.И., Михайлов Г.А., Назаралиев М.А., Дарбинян Р.А. Решение прямых и некоторых обратных задач атмосферной оптики методом Монте-Карло. Новосибирск: Наука, 1968. 100 с. 
116. Метод Монте-Карло в атмосферной оптике / Под ред. Г.И.Марчука. Новосибирск: Наука, 1976. 283 с.

117. Смоктий О.И. Моделирование полей излучения в задачах космической спектрофотометрии / АН СССР. Ин-т информатики и автоматизации. Л.: Наука, 1986. 352 с.

118. Сушкевич Т.А. Осесимметричная задача о распространении излучения в сферической системе // Труды ИПМ АН СССР. O-572-66. М.: ИПМ АН CCCP, 1966. $180 \mathrm{c}$.

119. Сушкевич T.A. Некоторые качественные закономерности радиационного поля Земли // В сб.: "8-е научное совещание по оптике атмосферы и актинометрии. Тезисы докладов". Томск: Изд. ИОА СО АН СССР, 1970. C. $15-16$.

120. Сушкевич Т.А. Об одном методе решения уравнения переноса для задач с двумерной сферической геометрией // Препринты ИПМ АН СССР. 1972. № 15. 31 с. Депонирован, № 5557-73 от 28.02.73.

121. Сушкевич Т.А. Поле яркости сферической атмосферы. Автореферат диссертации кандидата физ.-мат. наук, Москва. Институт физики атмосферы AH CCCP. 1972. $11 \mathrm{c}$.

122. Сушкевич Т.А. Математические модели переноса излучения. М.: БИНОМ. Лаборатория знаний, 2005. 661 с. (при поддержке РФФИ)

123. Lenoble J., Sekera Z. Equation of radiative transfer in a planetary spherical atmosphere // Proceedings of National Academy of Science USA. 1961. Vol. 47. № 3. P. 372-378.

124. Lenoble J. Radiative transfer in scattering and absorbing atmospheres: standard computational procedures. A Division of Science and Technology Corporation, Hampton, Virginia USA. A.DEEPAK Publishing, 1985. 583 p. (Ленобль Ж. Перенос радиации в рассеивающих и поглощающих атмосферах. Стандартные методы расчета / пер. с англ. К.С.Шифрина. Л.: Гидрометеоиздат, 1990. 263 c.)

125. Rosen James M. Stratospheric dust and its relationship to the meteoric influx // Space Science Reviews. 1969. V. 9, № 1. P. 58-89. https://link.springer.com/article/10.1007/BF00187579

126. Асатуров М.Л., Будыко М.И. и др. Вулканы, стратосферный аэрозоль и климат Земли. JL: Гидрометеоиздат, 1986. $256 \mathrm{c.}$

127. К 80-летнему юбилею академика Ю.А.Израэля. М.: Институт глобального климата и экологии Росгидромета и РАН, 2010.

http://www.igce.ru/page/izrael80

128. Антропогенные изменения климата / Коллективная монография Борзенкова И.И., Будыко М.И., Бютнер Э.К. и др. / Под ред. М.И.Будыко и Ю.А.Израэля. Л.: Гидрометеоиздат, 1987. 405 с. https://search.rsl.ru/ru/record/01001373900 
129. Парижское соглашение согласно Рамочной конвенции Организации Объединенных Наций об изменении климата («Парижское соглашение»). ООН. 2016. 19 c. (paris_agreement_russian_.pdf )

130. Гинзбург А.С., Губанова Д.П., Минашкин В.М. Влияние естественных и антропогенных аэрозолей на глобальный и региональный климат // Российский химический журнал. 2008. Т. 52. № 5. С. 112-119.

131. Физика образования осадков: Физика процессов образования осадков и искусственных воздействий на облака / Сборник статей. Пер. с англ., фр. и нем. / Под ред. Б.В.Дерягина и А.Х.Хргиана. М.: Издательство иностранной литературы, 1951. 255 c. https://search.rsl.ru/ru/record/01006043855

132. Вулканы. Оперативно, достоверно. http://izverzhenie-vulkana.ru

133. Аэрозоль и оптика атмосферы (К столетию Г.В.Розенберга) // Тезисы докладов. Международная конференция, 21-24 октября 2014. М.: Институт физики атмосферы им. А.М.Обухова РАН, 2014. 112 с.

http://www.ifaran.ru/science/conferences/Rozenberg2014.html

134. Розенберг Г.В. Особенности поляризации света, рассеянного атмосферой в условиях сумеречного освещения. Автореферат диссертации кандидата физ.-мат. наук, Москва. 1946.

\section{Оглавление}

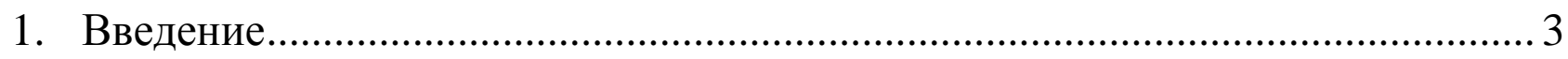

2. Как вулкан Агунг помог обнаружить стратосферные аэрозольные слои

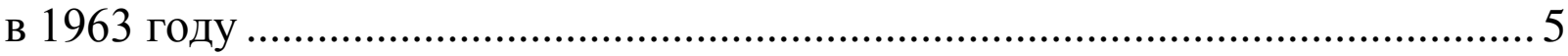

3. Сумеречный метод дистанционного зондирования атмосферы ………........... 7

4. Сферическая модель поля яркости атмосферы Земли и результаты первого научного эксперимента ............................................................... 12

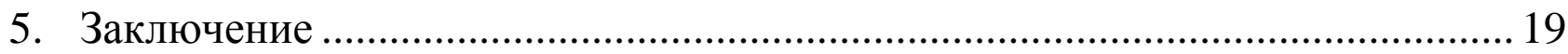

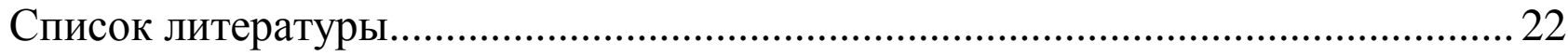

